\title{
Characterization of Crude Xylanase Produced by Edible Mushroom Pleurotus eryngii
}

Simair A Altaf ${ }^{\star *}$, Mangrio G Sughra², Thebo K Nasreen ${ }^{3}$, Dahot M Umar², Mangrio M Sher ${ }^{3}$, Khaskheli M Noor-e-Saba², Raja K Fariha1 and Changrui Lu'

${ }^{1}$ College of Chemistry, Chemical Engineering and Biotechnology, Donghua University, Shanghai, China

${ }^{2}$ Institute of Biotechnology and Genetic Engineering, University of Sindh, Jamshoro, Pakistan

${ }^{3}$ Institute of Plant Sciences, University of Sindh, Jamshoro, Pakistan

\begin{abstract}
Xylanase has been increasingly forthcoming in recent years because of their possible involvement in numerous industrial processes including bioconversion of lignocellulose derived sugars in to fuels, processing food and the paper and fiber industries. Edible mushrooms are emerging as important source of xylanolytic enzymes and this study has concentrated to produce and characterize xylanases by Pleurotus eryngii. The crude enzyme was characterized on the basis of various parameters such as incubation time, substrate specificity, substrate concentration, enzyme volume, buffer, $\mathrm{pH}, \mathrm{pH}$ stability, temperature, temperature stability, and effect of various metal ions or compounds. The xylanase activity was noted maximum at 15 minutes of incubation time, $2.0 \%$ xylan and $0.5 \mathrm{ml}$ enzyme volume. The highest enzyme activity was found at $\mathrm{pH} 4.5$, whereas xylanase exhibited maximum stability in the range of $\mathrm{pH} 4.0$ to 10.0 . The maximum xylanase activity was noted at $60^{\circ} \mathrm{C}$, while enzyme was most active and retains more than $40 \%$ activity at $90^{\circ} \mathrm{C}$ within 10 minutes of incubation. $\mathrm{ZnCl}_{2}(10 \mathrm{mM})$ stimulated the xylanase activity as compare to other metal ions or compounds. It is concluded that Pleurotus eryngii is capable to produce pH stable and thermostable xylanase for industrial purposes.
\end{abstract}

Keywords: Characterization; Xylanase; Edible mushroom; Pleurotus eryngii

\section{Introduction}

The plant cell wall is the most abundant reservoir of lignocellulosic material in the biosphere and degradation takes place by microbial enzymes is a key biological process that is central to the carbon cycle, herbivore nutrition and host invasion by phytopathogenic fungi and bacteria. Xylan, the main component of hemicellulose consists of $\alpha-1$, 4-linked d-xylosyl residues backbone branched with other pentoses, hexoses and uronic acids. Xylanases and associated debranching enzymes produced by a variety of microorganisms, which bring about the hydrolysis of Xylobiose of hemicelluloses $[1,2]$.

While xylanases have been reported from fungi [3], bacteria [4], actinomycetes [5,6], and yeast [7-9], there have been few studies using edible fungi as a xylanase source [10]. There are three reasons for using edible fungi as xylanase sources. First, mushrooms produce a wide range of extra-cellular enzymes that enable them to degrade complex lignocelluloses substrates into soluble substances [11]. Second, xylanase from edible fungi is an extra-cellular enzyme, with more than $90 \%$ of the xylanase from the mushroom secreted out of cells by T. Clypeatues [12]. Third edible mushroom protein is safe and highly nutritional [13]. Many of these fungi are also the source of highvalue metabolites of interest to the pharmaceutical, food and cosmetic industries [14,15]. The objective of this study was to characterize xylanase enzyme, produced by Pleurotus eryngii grown on $0.6 \%$ starch as a main substrate in liquid-state culture and examined the effects of $\mathrm{pH}$, temperature and metal ions on crude xylanase stability. To our knowledge, this is the first report describing the characterization of xylanase by edible mushroom Pleurotus eryngii.

\section{Materials and Methods}

\section{Fungal strain}

In this study, mushroom strain Pleurotus eryngii was purchased from Edible fungi Institute, Shanghai Academy of Agricultural
Sciences Shanghai, China. Stock cultures of these fungi are maintained on Potato dextrose agar slants at $4^{\circ} \mathrm{C}$.

\section{Inoculum preparation}

The inoculum was prepared by growing mushrooms on a rotary shaker at $120 \mathrm{rpm}$ and $27 \pm 2^{\circ} \mathrm{C}$ in $250 \mathrm{ml}$ Erlenmeyer flasks containing $50 \mathrm{ml}$ of following synthetic medium (per liter) $6.0 \mathrm{~g}$ glucose, $0.2 \mathrm{~g}$ yeast extract, $0.5 \mathrm{~g}$ peptone, $1.0 \mathrm{~g} \mathrm{KH}_{2} \mathrm{PO}_{4}$ and $0.5 \mathrm{~g} \mathrm{MgSO}_{4} \cdot 7 \mathrm{H}_{2} \mathrm{O}$. The medium was adjusted to $\mathrm{pH} 5.5$ with $0.1 \mathrm{~N} \mathrm{HCl}$ or $\mathrm{NaOH}$. After 4 days of cultivation mycelial pellets of Pleurotus eryngii were harvested and homogenized with a laboratory blender.

\section{Culture conditions}

Lignocellulosic substrates submerged fermentation has been carried out on a rotary shaker at $120 \mathrm{rpm}$ and $27 \pm 2^{\circ} \mathrm{C}$ in $250 \mathrm{ml}$ Erlenmeyer flasks containing $50 \mathrm{ml}$ of above-mentioned medium with different carbon sources (glucose, xylose, sucrose, starch, xylan, wood straw and rice husk powder) with $0.2,0.4$ and $0.6 \%$ concentrations $\mathrm{g} / \mathrm{L}$. The initial $\mathrm{pH}$ of the medium was adjusted to 5.5 prior to sterilization by using $0.1 \mathrm{~N} \mathrm{HCl}$ or $\mathrm{NaOH}$. $1.0 \mathrm{ml}$ of mycelial homogenate was used to inoculate the Erlenmeyer flasks containing media. After 96 hours of mushroom cultivation, when cultures reached end of logarithmicstationary phase of growth, the extracellular enzymes were extracted in

*Corresponding author: Simair A Altaf, College of Chemistry, Chemical Engineering and Biotechnology, Donghua University, Shanghai, China, Tel: +8618301817325; E-mail: altafsimair@dhu.edu.cn

Received December 31, 2015; Accepted January 30, 2016; Published February 04 2016

Citation: Altaf SA, Sughra MG, Nasreen TK, Umar DM, Sher MM, et al. (2016) Characterization of Crude Xylanase Produced by Edible Mushroom Pleurotus eryngii. J Bioprocess Biotech 6: 268. doi:10.4172/2155-9821.1000268

Copyright: $\odot 2016$ Altaf SA, et al. This is an open-access article distributed under the terms of the Creative Commons Attribution License, which permits unrestricted use, distribution, and reproduction in any medium, provided the original author and source are credited. 
order to measure the $\mathrm{pH}$ of culture medium and enzyme activity. The mycelial biomass was separated by filtration through Whatman filter paper No.1 and followed by centrifugation $(5000 \mathrm{~g} ; 15 \mathrm{~min})$ at $4^{\circ} \mathrm{C}$ and the final $\mathrm{pH}$ was measured by (WAPA) $\mathrm{pH}$ meter.

\section{Enzyme assay}

Xylanase activity was determined by mixing $0.5 \mathrm{ml}$ sample with $0.5 \mathrm{ml}$ of oat to xylan (Fluka, Germany) $(1 \% \mathrm{w} / \mathrm{v})$ in $50 \mathrm{mM}$ citrate buffer ( $\mathrm{pH} 5.3$ ) at $60^{\circ} \mathrm{C}$ for $15 \mathrm{~min}$ reported by Bailey et al. [16]. Xylose standard curve was used to calculate the xylanase activity. In assay the release of reducing sugars were measured by using dinitrosalicylic acid reagent method [17]. One International unit of enzyme activity was defined as the amount of enzyme, releasing $1 \mu \mathrm{mol}$ of reducing sugars per minute $\mathrm{ml}^{-1}$.

\section{Results and Discussion}

The effect of time period and carbon sources on the production of xylanase by Pleurotus eryngii was checked and it is concluded from the outcome of the present study as shown in Figures 1-3 and Table 1 that the addition of different carbon sources were enhanced the xylanase production and result reveals that incubation period varies from carbon source to carbon source. However, after 96 hours a decrease in enzyme production was observed when starch was used as a carbon source for the growth and xylanase production that may be due to the exhaustion of nutrients from the medium that affected the organism's growth. Other factor, glucose is the end product of starch so in my study glucose has shown repressed expression, which is also supported by early investigators [18-20]. After optimizing carbon source, nitrogen sources were optimized with two different concentrations ( 0.5 and $1.0 \%$ ) and incorporated with $0.6 \%$ starch in the fermentation medium for the growth and xylanase production of Pleurotus eryngii. Among the nitrogen sources used $1.0 \%$ corn steep liquor was found best for xylanase production as shown in Table 2 .

The crude xylanase produced by Pleurotus eryngii when grown on $0.6 \%$ starch, $0.5 \%$ corn steep liquor and $0.05 \%$ valine incubated at $30^{\circ} \mathrm{C}$ for 96 hours and $\mathrm{pH}$ was adjusted to 7.0 was characterized on the basis of time of incubation, substrate specificity, substrate concentration, enzyme volume, buffer, $\mathrm{pH}, \mathrm{pH}$ stability, temperature, thermostability, activators and inhibitors.

The xylanase activity of Pleurotus eryngii was observed highest up to 15 minutes at $60^{\circ} \mathrm{C}$ and then gradually declined as shown in Figure 4 . The reason behind the decrease in xylanase activity might be inactivation of enzyme on prolong incubation or self digestion $[21,22]$. Similar results are reported from earlier studies [23,24]. Figure 5 shows the substrate specificity xylan was replaced with various substrates such as CM-cellulose, avicel, cellulose and starch. The 100\% relative higher activity was observed by $2.0 \%$ xylan. Figure 6 shows the effect of substrate concentration (xylan $0.5-4.0 \%$ ) on xylanase activity produced by Pleurotus eryngii. Xylanase activity was increased with increase of xylan concentration up to $2.0 \%$ and later on activity was gradually decreased. The declination of xylanase activity may be due to alteration in enzyme and substrate ratio. The effect of crude enzyme volume $(0.1-1.0 \mathrm{ml})$ was also checked on Pleurotus eryngii xylanase activity. The higher xylanase activity was found using $0.5 \mathrm{ml}$ crude enzyme while low xylanase activity was observed when less amount of enzyme volume was used so it could be due to insufficient amount of enzyme to hydrolyze available substrate as shown in Figure 7. Figure 8 shows the effect of different buffers (sodium phosphate, sodium citrate and universal buffer (0.05 M. pH 5.5) on xylanase activity. The $100 \%$

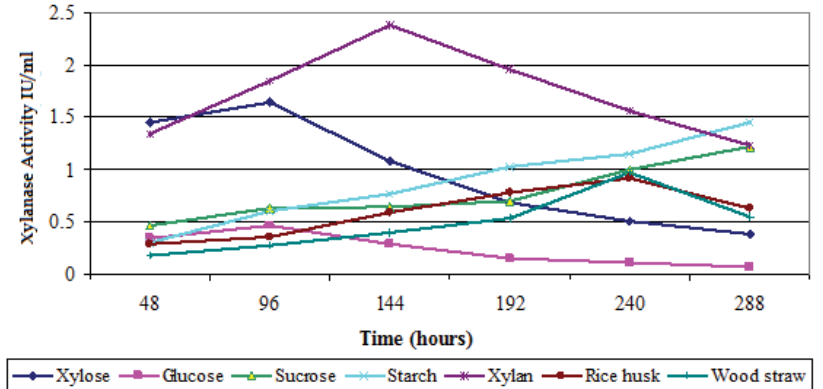

Figure 1: Effect of $0.2 \%$ carbon sources on growth and xylanase production by Pleurotus eryngii after 288 hours of incubation period.

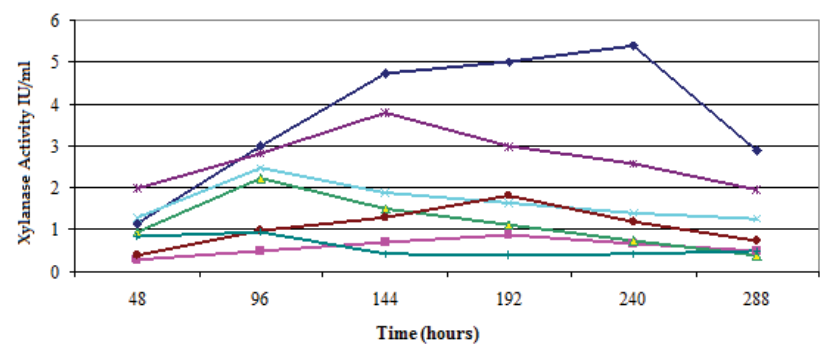

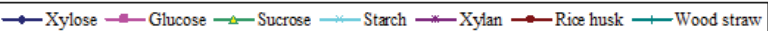

Figure 2: Effect of $0.4 \%$ carbon sources on growth and xylanase production by Pleurotus eryngii after 288 hours of incubation period.

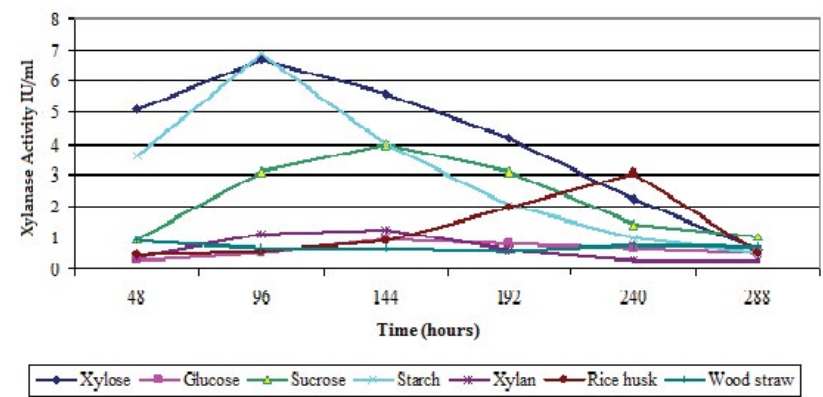

Figure 3: Effect of $0.6 \%$ carbon sources on growth and xylanase production by Pleurotus eryngii after 288 hours of incubation period.

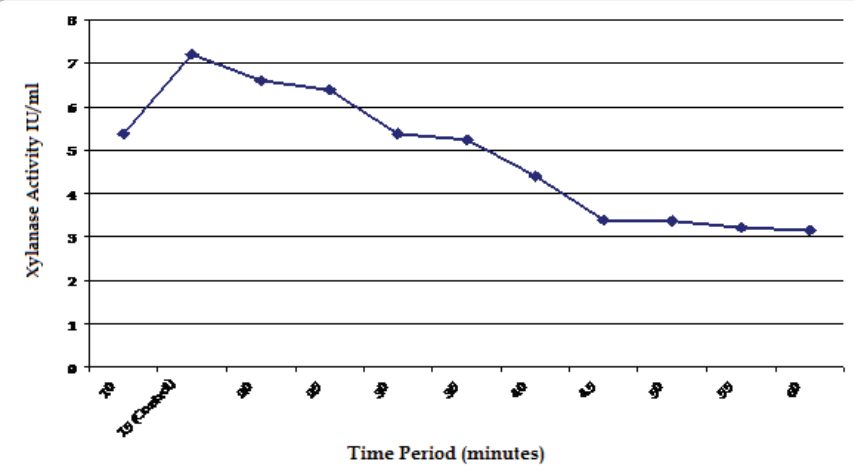

SD: Standard Deviation; SE: Standard Error; Minimum: 2.1150; Maximum 7.4800; Sum: 42.296; Mean: 5.2870; Variance: 3.5130; SD: 1.8743; SE Mean: 0.6627

Figure 4: Effect of time of incubation on crude xylanase. 


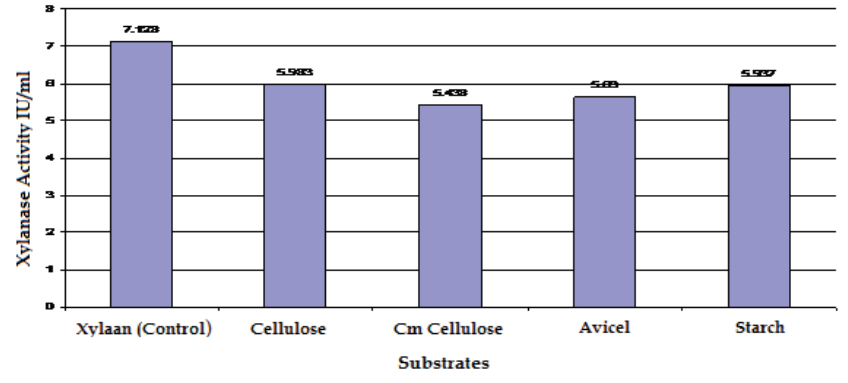

SD: Standard Deviation; SE: Standard Error; Minimum: 5.4380; Maximum: 7.1280; Sum: 30.116; Mean: 6.0232; Variance: 0.4317; SD: 0.6570; SE Mean: 0.2938

Figure 5: Effect of substrate specificity on crude xylanase.

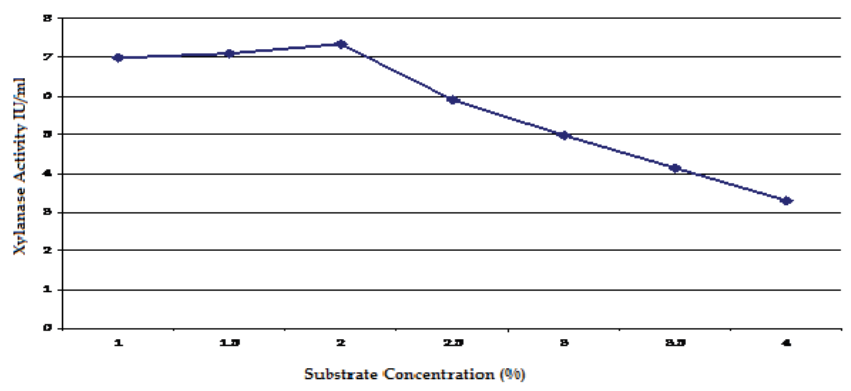

SD: Standard Deviation; SE: Standard Error; Minimum: 3.3020; Maximum: 7.3450; Sum: 39.759; Mean: 5.6799; Variance: 2.5078; SD: 1.5836; SE: 0.5985

Figure 6: Effect of substrate concentration on crude xylanase.

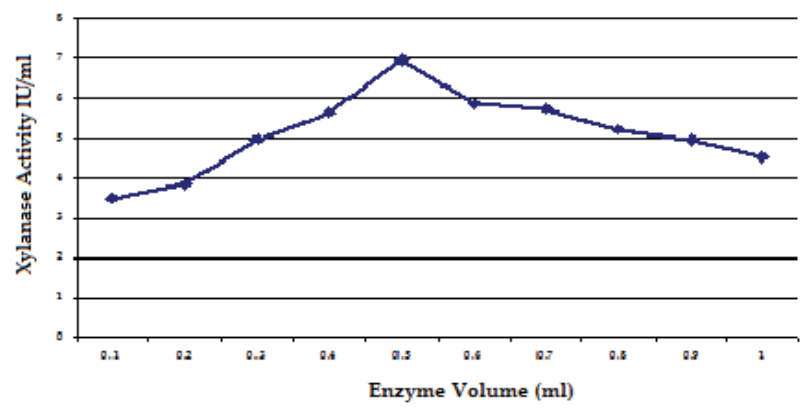

SD: Standard Deviation; SE: Standard Error; Minimum: 3.4910; Maximum 6.9670; Sum: 30.739; Mean: 5.1232; Variance: 1.7009; SD: 1.3042; SE: 0.532

Figure 7: Effect of enzyme volume on crude xylanase.

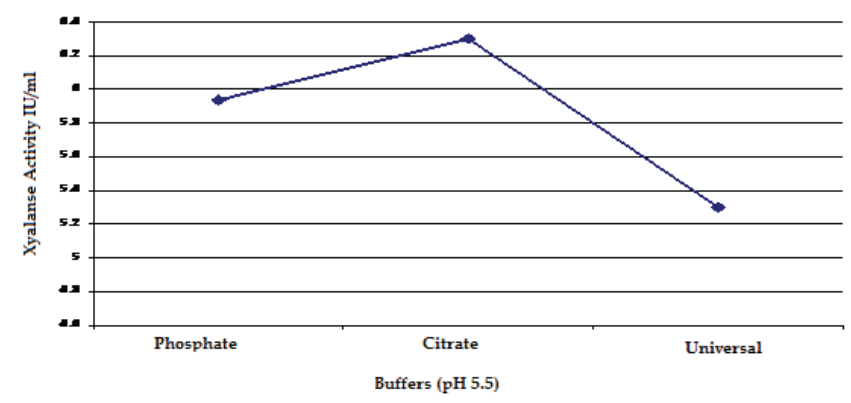

SD: Standard Deviation; SE: Standard Error; Minimum: 5.2990; Maximum: 6.3010; Sum: 17.538; Mean: 5.8460; Variance: 0.2573; SD: 0.5073; SE: 0.2929

Figure 8: Effect of different buffers on crude xylanase.

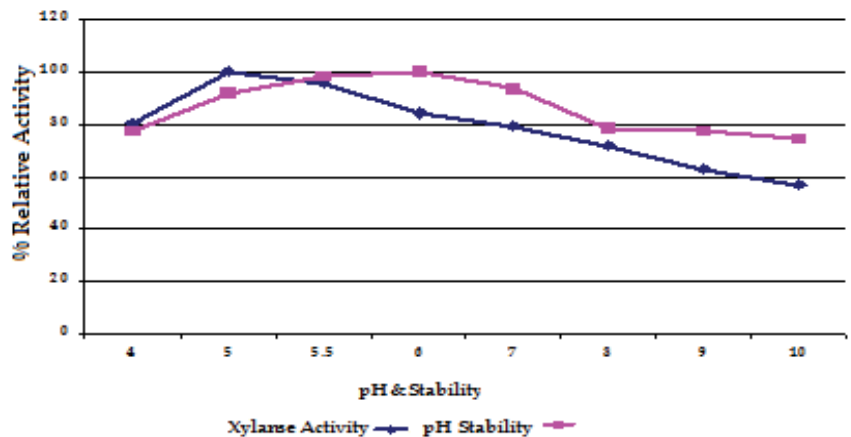

(a) Effect of $\mathrm{pH}$ (b) $\mathrm{pH}$ stability; SD: Standard Deviation; SE: Standard Error Minimum a: 74.420; Maximum a: 100.00; Sum a: 664.62; Mean a: 83.077 ; Variance a: 82.316; SD a: 9.0728; SE a: 3.2077; Minimum b: 74.420; Maximum b: 100.00; Sum b: 664.62; Mean b: 83.077; Variance b: 82.316 ; SD b: 9.0728 ; SE b: 3.2077

Figure 9: Effect of $\mathrm{pH}$ and stability on crude xylanase.

relative activity was determined by using sodium citrate buffer which was used throughout the study. The use of sodium citrate buffer in xylanase activity is reported by Salama et al. [25].

Figure 9 shows the effect of $\mathrm{pH}$ and $\mathrm{pH}$ stability on xylanase activity synthesized by Pleurotus eryngii using sodium citrate buffer ranging from $\mathrm{pH}$ 3.0-10.0. The maximum activity was determined at $\mathrm{pH}$ 5.0. The similar results have been reported by Franco et al., Ximenes et al. and Chipeta et al. [26-28]. The pH stability of xylanase was also checked using sodium citrate buffer ranging from $\mathrm{pH}$ 3.0-10.0 when enzyme was incubated for 10 minutes without substrate. After 10 minutes substrate was added and assay was carried out at $60^{\circ} \mathrm{C}$. Xylanase showed maximum $\mathrm{pH}$ stability in-between $\mathrm{pH} 5.0$ to 7.0. The similar results are reported by Ref. [29-32].

Figure 10 shows the effect of temperature and temperature stability ranging from $10-100^{\circ} \mathrm{C}$ on crude xylanase activity. The xylanase activity increased due to the enzyme catalyzed reaction up to $60^{\circ} \mathrm{C}$ and also due to the increase in the number of collisions between the reacting molecules. But, the enzyme probably got denatured on exposure to higher temperatures than its optimum and therefore, steadily lost its activity when incubated for 15 minutes with sodium citrate buffer $\mathrm{pH}$ 5.0. These findings are in accordance with several earlier reports showing optimal xylanase activity at $60^{\circ} \mathrm{C}$ by Balakrishnan $\mathrm{H}$ et al. [3335]. $100 \%$ relative xylanase activity was measured after incubation at $60^{\circ} \mathrm{C}$ for 15 minutes and high optimum temperature may have striking effect on industrial purpose. The thermostability was checked by heating enzyme for 10 minutes at different temperatures ranging from $10-100^{\circ} \mathrm{C}$. More than $40 \%$ activity was retained within 10 minutes at $100^{\circ} \mathrm{C}$ that proves xylanase activity is thermostable.

Figure 11 shows the effect of various metal ions or compounds ( $5 \mathrm{mM}$ ) on xylanase activity produced by Pleurotus eryngii. The xylanase activity was activated by metal ions such as $\mathrm{Zn}^{2+}$ and $\mathrm{Ca}^{2+}$ that suggests xylanase is a metalloenzyme. Xylanase is strongly inhibited by EDTA. The maximum activity was noted with $10 \mathrm{mM} \mathrm{ZnCl}_{2} 114 \%$ and $\mathrm{CaCl}_{2} 105 \%$ respectively. It has been reported that the divalent metals enhance xylanase activity [36-39]. Figure 12 shows effect of different concentrations $(2.5-15.0 \mathrm{mM})$ of the best activator and was observed that xylanase activity increased with the increase of $\mathrm{ZnCl}_{2}$ concentration and $100 \%$ relative activity was noted with $10 \mathrm{mM} \mathrm{ZnCl}_{2}$. This was also observed that with the increase of $\mathrm{ZnCl}_{2}$ concentration decreased the enzyme activity and it may be due to the higher amount 
Citation: Altaf SA, Sughra MG, Nasreen TK, Umar DM, Sher MM, et al. (2016) Characterization of Crude Xylanase Produced by Edible Mushroom Pleurotus eryngii. J Bioprocess Biotech 6: 268. doi:10.4172/2155-9821.1000268

Page 4 of 6

\begin{tabular}{|c|c|c|c|}
\hline & Carbon sources \% & Biomass $\mathrm{g} / 50 \mathrm{ml}$ & Xylanase Activity IU/ml \\
\hline \multirow[t]{3}{*}{ Xylose } & 0.2 & 0.05 & 1.635 \\
\hline & 0.4 & 0.02 & 5.35 \\
\hline & 0.6 & 0.02 & 6.068 \\
\hline \multirow[t]{3}{*}{ Glucose } & 0.2 & 0.043 & 0.46 \\
\hline & 0.4 & 0.11 & 0.88 \\
\hline & 0.6 & 0.11 & 0.92 \\
\hline \multirow[t]{3}{*}{ Sucrose } & 0.2 & 0.19 & 1.21 \\
\hline & 0.4 & 0.27 & 2.205 \\
\hline & 0.6 & 0.25 & 6.53 \\
\hline \multirow[t]{3}{*}{ Starch } & 0.2 & 0.02 & 1.443 \\
\hline & 0.4 & 0.027 & 2.46 \\
\hline & 0.6 & 0.026 & 6.83 \\
\hline \multirow[t]{3}{*}{ Xylem } & 0.2 & 0.048 & 2.383 \\
\hline & 0.4 & 0.048 & 3.77 \\
\hline & 0.6 & 0.051 & 1.258 \\
\hline \multirow[t]{3}{*}{ Wood straw } & 0.2 & 0.02 & 0.961 \\
\hline & 0.4 & 0.02 & 0.832 \\
\hline & 0.6 & 0.012 & 0.85 \\
\hline \multirow[t]{3}{*}{ Rice husk } & 0.2 & 0.007 & 0.912 \\
\hline & 0.4 & 0.007 & 1.818 \\
\hline & 0.6 & 0.011 & 3.069 \\
\hline
\end{tabular}

a: Biomass g/50 ml; b: Xylanase Activity IU/ml; SD: Standard Deviation; SE: Standard Error; Minimum a: 0.007; Maximum a: 0.0.270; Sum: 1.360; Mean: 0.065; Variance a: 0.006; SD a: 0.078; SE a: 0.017; Minimum b: 0.460; Maximum b: 6.830; Sum: 50.844; Mean: 2.421; Variance b: 4.071; SD b: 2.018; SE b: 0.440; \pm indicated standard deviation from mean value

Table 1: Effect of different carbon sources on growth and xylanase production by Pleurotus eryngii.

\begin{tabular}{|c|c|c|c|}
\hline & Nitrogen sources \% & Biomass $\mathrm{g} / 50 \mathrm{ml}$ & Xylanase Activity IU/mI \\
\hline \multirow[t]{2}{*}{$\mathrm{KNO}_{3}$} & 0.5 & 0.043 & 2.82 \\
\hline & 1.0 & 0.037 & 3.671 \\
\hline \multirow[t]{2}{*}{$\mathrm{NaNO}_{3}$} & 0.5 & 0.047 & 3.541 \\
\hline & 1.0 & 0.064 & 3.863 \\
\hline \multirow[t]{2}{*}{$\left(\mathrm{NH}_{4}\right)_{2} \mathrm{HPO}_{4}$} & 0.5 & 0.061 & 2.64 \\
\hline & 1.0 & 0.054 & 3.01 \\
\hline \multirow[t]{2}{*}{ Urea } & 0.5 & 0.062 & 2.95 \\
\hline & 1.0 & 0.067 & 3.16 \\
\hline \multirow[t]{2}{*}{ Corn steep liquor } & 0.5 & 0.072 & 6.530 \\
\hline & 1.0 & 0.083 & 7.185 \\
\hline
\end{tabular}

a: Biomass g/50 ml; b: Xylanase Activity IU/ml; SD: Standard Deviation; SE: Standard Error; Minimum a: 0.037; Maximum a: 0.083; Sum: 0.590; Mean: 0.059; Variance a: 0.000; SD a: 0.014; SE a: 0.004; Minimum b: 2.640; Maximum b: 7.185; Sum: 39.370; Mean: 3.937; Variance b: 2.541; SD b: 1.594; SE b: 0.504; \pm indicated standard deviation from mean value.

Table 2: Effect of nitrogen sources on growth and xylanase production by Pleurotus eryngii.

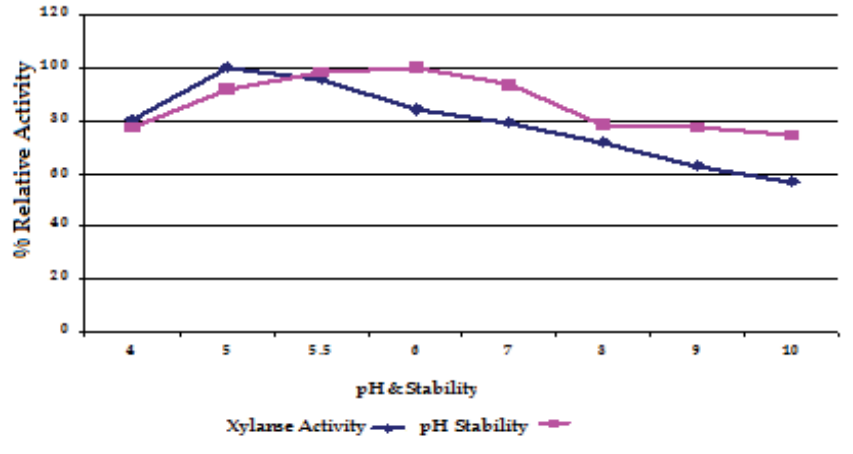

(a) Temperature (b) Temperature stability; SD: Standard Deviation; SE: Standard Error; Minimum a: 45.550; Maximum a: 100.00; Sum a: 652.14; Mean a: 65.214; Variance a: 333.27; SD a: 18.256; SE a: 5.7729; Minimum b: 41.580 ; Maximum b: 100.00; Sum b: 796.36; Mean b: 79.636; Variance b: 662.75 SD b: 25.744; SE b: 8.1409

Figure 10: Effect of temperature and stability on crude xylanase.

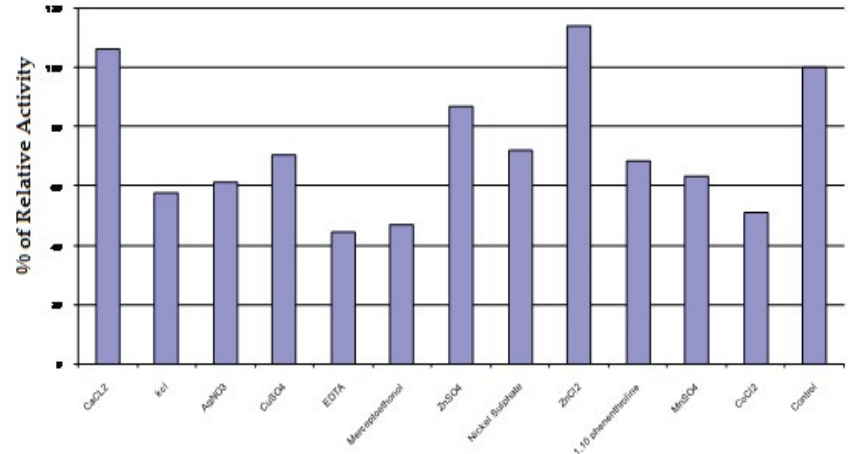

Metal ions/Compounds

SD: Standard Deviation; SE: Standard Error; Minimum: 44.650; Maximum: 114.05; Sum: 980.45; Mean: 75.419; Variance: 519.21; SD: 22.786; SE: 6.3198

Figure 11: Effect of $(5 \mathrm{mM})$ metal ions or compounds on crude xylanase. 
Citation: Altaf SA, Sughra MG, Nasreen TK, Umar DM, Sher MM, et al. (2016) Characterization of Crude Xylanase Produced by Edible Mushroom Pleurotus eryngii. J Bioprocess Biotech 6: 268. doi:10.4172/2155-9821.1000268

Page 5 of 6

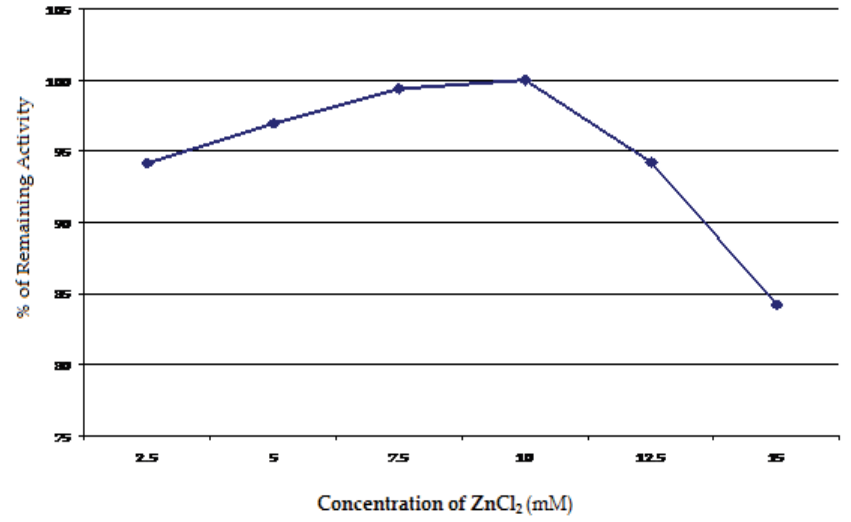

SD: Standard Deviation; SE: Standard Error; Minimum: 84.230; Maximum 100.00; Sum: 568.91; Mean: 94.818; Variance: 33.082; SD: 5.7517; SE: 2.3481

Figure 12: Effect of different concentrations (2.5-15.0mM) of $\mathrm{ZnCl}_{2}$ as activator.

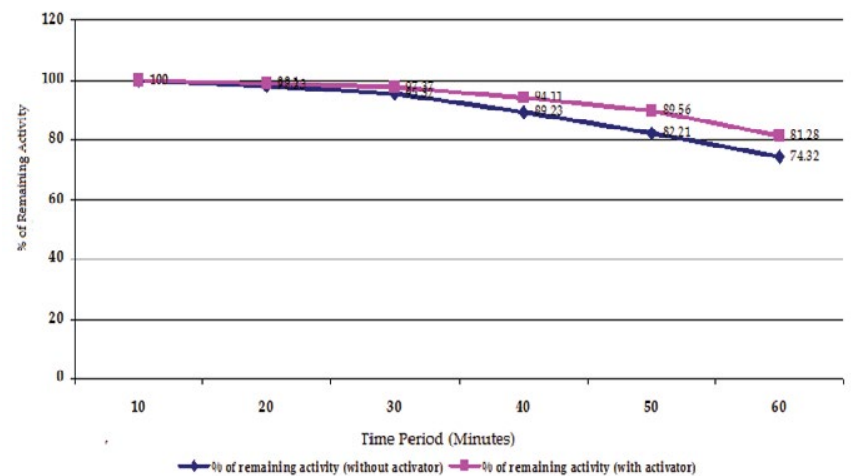

(a) Without activator (b) With activator; SD: Standard Deviation; SE: Standard Error; Minimum a: 74.320; Maximum a: 100.00; Sum a: 539.31; Mean a: 89.885 ; Variance a: 100.62; SD a: 10.031; SE a: 4.0951; Minimum b: 81.280; Maximum b: 100.00; Sum b: 561.42; Mean b: 93.570 ; Variance b 50.756 ; SD b: 7.1243 SE b: 2.9085

Figure 13: Effect of thermostability at $60^{\circ} \mathrm{C}$ with and without activator $(10 \mathrm{mM}$ $\mathrm{ZnCl}_{2}$ ) on different time periods.

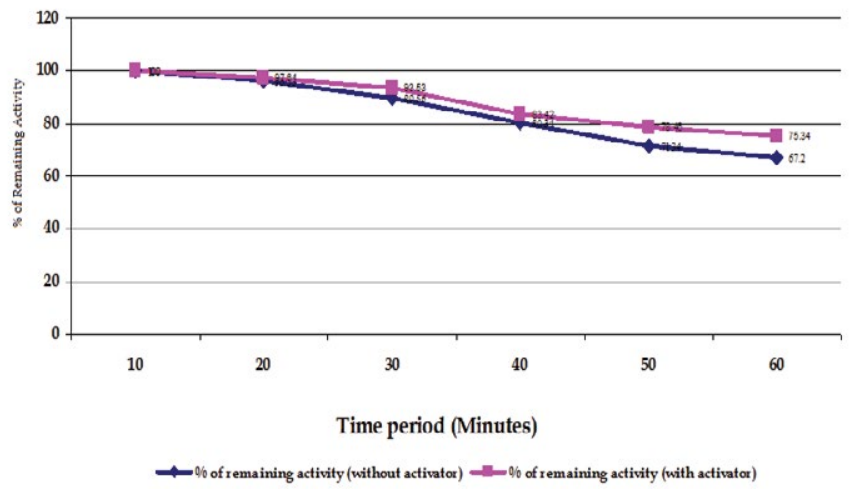

(a) Without activator (b) With activator; SD: Standard Deviation; SE: Standard Error; Minimum a: 67.200; Maximum a: 100.00; Sum a: 504.97; Mean a: 84.162 Variance a: 179.93; SD a: 13.414; SE a: 5.4762; Minimum b: 75.340; Maximum b: 100.00; Sum b: 528.39; Mean b: 88.065 ; Variance b: 107.95 ; SD b: 10.390 SE b: 4.2417

Figure 14: Effect of thermostability at $70^{\circ} \mathrm{C}$ with and without activator $(10 \mathrm{mM}$ $\mathrm{ZnCl}_{2}$ ) on different time periods. of activator, which acts as inhibitor.

Figures 12 and 13 show thermostability of crude xylanase at fixed temperatures $60^{\circ} \mathrm{C}$ and $70^{\circ} \mathrm{C}$ respectively with varying time of incubation (10-60 minutes) with and without $\mathrm{ZnCl}_{2}$. It was observed that xylanase activity was decreased with increasing time of incubation in all cases but in the case of without activator, activity was lower in comparison to $10 \mathrm{mM} \mathrm{ZnCl}$ as an activator at $60^{\circ} \mathrm{C}$ and $70^{\circ} \mathrm{C}$. More than $80 \%$ and $75 \%$ xylanase activity was retained at $60^{\circ} \mathrm{C}$ and $70^{\circ} \mathrm{C}$ respectively after 60 minutes of incubation with activator $\left(\mathrm{ZnCl}_{2}\right)$ (Figure 14).

\section{Conclusion}

According to this study, crude enzyme characterization proved that enzyme is thermostable and $\mathrm{pH}$ stable, which is suitable for industrial use and xylanase produced by Pleurotus eryngii can be cost effective and helpful for pulp and paper industries by saving large amount of foreign exchange.

\section{References}

1. Gilbert HJ, Hazlewood GP (1993) Bacterial cellulases and xylanases. J Gen Microbiol 139: 187-194.

2. Maheshwari R, Bharadwaj G, Bhat MK (2000) Thermophilic fungi: their physiology and enzymes. Microbiol Mol Biol Rev 64: 461-488.

3. Gawande PV, Kamat MY (1999) Production of Aspergillus xylanase by lignocellulosic waste fermentation and its application. J Appl Microbiol 87: 511 519.

4. Rawashdeh R, Saadoun I, Mahasneh A (1995) Effect of cultural conditions on xylanase production by Streptomyces sp. (strain Ib 24D) and its potential to utilize tomato pomace. Afr J Biotechnol 4: 251-255.

5. Ball AS, McCarthy AJ (1989) Production and properties of xylanases from actinomycetes. J Appl Bacteriol 66: 439-444.

6. Beg QK, Bhushan B, Kapoor M, Hoondal GS (2000) Effect of amino acids on production of xylanase and pectinase from Streptomyces sp. QG-11-3. World J Microbiol Biotechnol 16: 211-213.

7. Liu W, Lu Y, Ma G (1999) Induction and glucose repression of endo-xylanase in the yeast Trichosporon cutaneum SL409. Process Biochem 34: 67-72.

8. Otero DM, Cadaval CL, Teixeira LM, Rosa CA, Sanzo AVL, et al. (2015) Screening of yeasts capable of producing cellulase-free xylanase. Afr J Biotechnol 14: 1961-1969.

9. Liu W, Zhu W, Lu Y, Kong J, Ma G (1998) Production, partial purification and characterization of xylanase from Trichosporon cutaneum SL409. Process Biochem 33: 331-336.

10. Hazra PP, Sengupta T, Mukhopadhyay A, Ghosh AK, Mukherjee M, et al. (1997) Regulation of protein secretion by mycelial culture of the mushroom Termitomyces clypeatus. FEMS Microbiol Lett 154: 239-243.

11. Baldrian P, Gabriel J (2003) Lignocellulose degradation by Pleurotus ostreatus in the presence of cadmium. FEMS Microbiol Lett 220: 235-240.

12. Ghosh M, Mukherjee R, Nandi B (1998) Production of extracellular enzymes by two Pleurotus species using banana pseudostem biomass. Acta Biotechnol 18: 243-254.

13. Chang ST, Buswell JA, Miles PG (1993) Genetics and breeding of edible mushrooms. Philadelphia: Gordon \& Breach Science Publishers.

14. Jong SC, Donovick R (1989) Antitumor and antiviral substances from fungi. Adv Appl Microbiol 34: 183-262.

15. Marquez Rocha FJ, Hernandez Rodriguez VZ, Vasquez Duhalt R (2000) Biodegradation of soil-adsorbed polycyclic aromatic hydrocarbons by the white-rot fungus Pleurotus ostreatus. Biotechnol Lett 22: 469-472.

16. Bailey MJ, Bailey P, Poutanen K (1992) Inter laboratory testing methods for the assay of xylanase activity. J Biotechnol 23: 257-270. 
Citation: Altaf SA, Sughra MG, Nasreen TK, Umar DM, Sher MM, et al. (2016) Characterization of Crude Xylanase Produced by Edible Mushroom Pleurotus eryngii. J Bioprocess Biotech 6: 268. doi:10.4172/2155-9821.1000268

17. Miller GL (1959) Use of dinitrosalicylic acid reagent for determination of reducing sugar. Analytical Chem 31: 426-429.

18. Zeilinger S, Mach RL, Schindler M, Herzog P, Kubicek CP (1996) Different inducibility of expression of the two xylanase genes xyn1 and xyn2 in Trichoderma reesei. J Biol Chem 271: 25624-25629.

19. Wang P, Ali S, Masson JC, Broda P (1992) Xylanases from fungi: properties and industrial applications. Appl Microbiol Biotechnol 67: 577-591.

20. Southerton SG, Osbourn AE, Dow JM, Daniels MJ (1993) Two xylanases from Gaeumannomyces graminis with identical N-terminal amino acid sequence. Physiol Molecul Plant Pathol 42: 97-107.

21. Mellors A, Tappel AL (1967) Hydrolysis of phospholipids by a lysosoma enzyme. J Lipid Res 8: 479-485.

22. Galliard T (1971) Enzymic deacylation of lipids in plants. The effects of free fatty acids on the hydrolysis of phospholipids by the lipolytic acyl hydrolase of potato tubers. Eur J Biochem 21: 90-98.

23. Farooq L, Asgher M, Saleem R, Akram A Legge R (2006) Purification and characterization of xylanase produced by Chaetomium thermophile NIBGE. World J Microbiol Biotechnol 22: 45-50.

24. Sapre MP, Jha H, Patil MB (2005) Purification and characterization of a thermoalkalophilic xylanase from Bacillus $\mathrm{sp}$. World J Microbiol Biotechnol 21: 649-654.

25. Salama MA, Ismail KMI, Amany HA, El-Lill A, Geweely NSI (2008) Biochemical studies of purified extracellular xylanases from Aspergillus versicolor. Int $J$ Botany 4: 41-48.

26. Franco PF, Ferreira HM, Filho EX (2004) Production and characterization of hemicellulase activities from Trichoderma harzianum strain T4. Biotechnol App Biochem 40: 255-259.

27. Ximenes FA, de Sousa MV, Puls J, da Silva FG Jr, Filho EXF (1999) Purification and characterization of a low-molecular-weight xylanase produced by Acrophialophora nainiana. Curr Microbiol 38: 18-21.
28. Chipeta ZA, du Preez JC, Szakacs G, Christopher L (2005) Xylanase production by fungal strains on spent sulphite liquor. Appl Microbiol Biotechnol 69: 71-78.

29. Terrasan CR, Temer B, Duarte MC, Carmona EC (2010) Production of xylanolytic enzymes by Penicillium janczewskii. Bioresour Technol 101: 41394143.

30. Isil S, Nilufer A (2005) Investigation of factors affecting xylanase activity from Trichoderma harzianum 1073 D3. Braz Arch Biol Technol 48: 187-193.

31. Dey D, Hinge J, Shendye A, Rao M (1992) Purification and properties of extracellular endoxylanases from alkalophilic thermophilic Bacillus sp. Can J Microbiol 38: 436-442.

32. Knob A, Beitel SM, Fortkamp D, Terrasan CR, de Almeida AF (2013) Production purification, and characterization of a major Penicillium glabrum xylanase using Brewer's spent grain as substrate. BioMed Res Int 2013: 728735.

33. Balakrishnan H, Dutta-Choudhury M, Srinivasan MC, Rele MV (1992) Cellulase-free xylanase production from an alkalophilic Bacillus species. World J Microbiol Biotechnol 8: 627-631.

34. Fernendez-Espinar M, Pinaga F, Sanaz P, Ramon D (1993) Purification and characterization of a neutral endoxylanase from Aspergillus nidulans. FEMS Microbiol Lett 113: 223-228.

35. Luceno-Neto SA, Ferrrira-Filho EX (2004) Purification and characterization of a new xylanase from Humicola grisea var tharmidea. Braz J Microbiol 35: 86-90.

36. Singh S, Madlala AM, Prior BA (2003) Thermomyces lanuginosus: properties of strains and their hemicellulases. FEMS Microbiol Rev 27: 3-16.

37. Dutta T, Sengupta R, Sahoo R, Sinha Ray S, Bhattacharjee A, et al. (2007) A novel cellulase free alkaliphilic xylanase from alkali tolerant Penicillium citrinum: production, purification and characterization. Lett Appl Microbiol 44: 206-211.

38. Khandeparkar R, Bhosle NB (2007) Application of thermoalkalophilic xylanase from Arthrobacter sp. MTCC 5214 in biobleaching of kraft pulp. Bioresour Technol 98: 897-903.

39. Mama G, Hatti-Kaul R, Mattiasson B (2006) A thermostable alkaline active endo3-1-4-xylanase from Bacillus halodurans S7: purification and characterization. Enz Microb Technol 39: 1492-1498. 